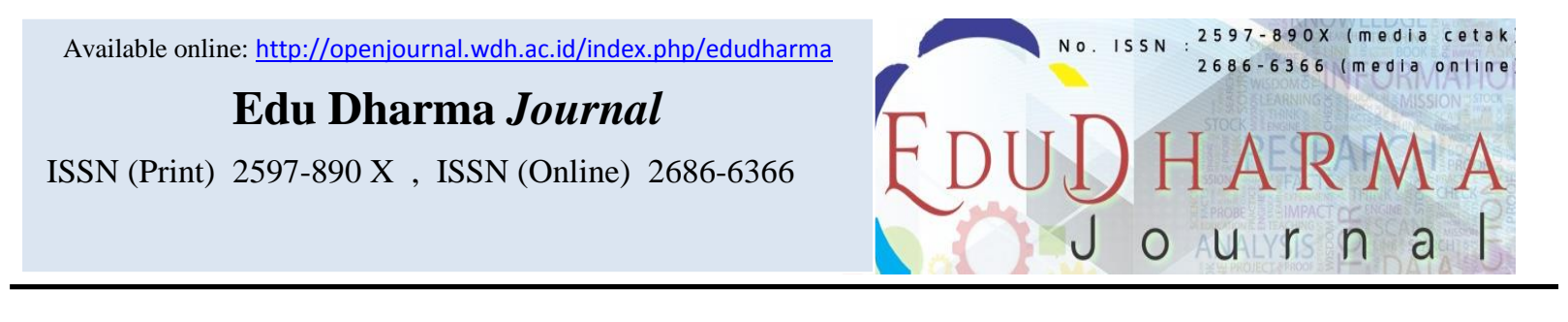

\title{
STUDI LITERATUR FAKTOR-FAKTOR YANG MEMPENGARUHI KEJADIAN DEPRESI POST PARTUM
}

\author{
Ikada Septi Arimurti ${ }^{1 *}$, Rita Dwi Pratiwi ${ }^{2}$, Amanda Rischa Ramadhina ${ }^{3}$ \\ ${ }^{1,2}$ Dosen STIKes Widya Dharma Husada Tangerang, Pamulang, Tangerang Selatan, Indonesia \\ ${ }^{3}$ Mahasiswa STIKes Widya Dharma Husada Tangerang, Pamulang, Tangerang Selatan, Indonesia
}

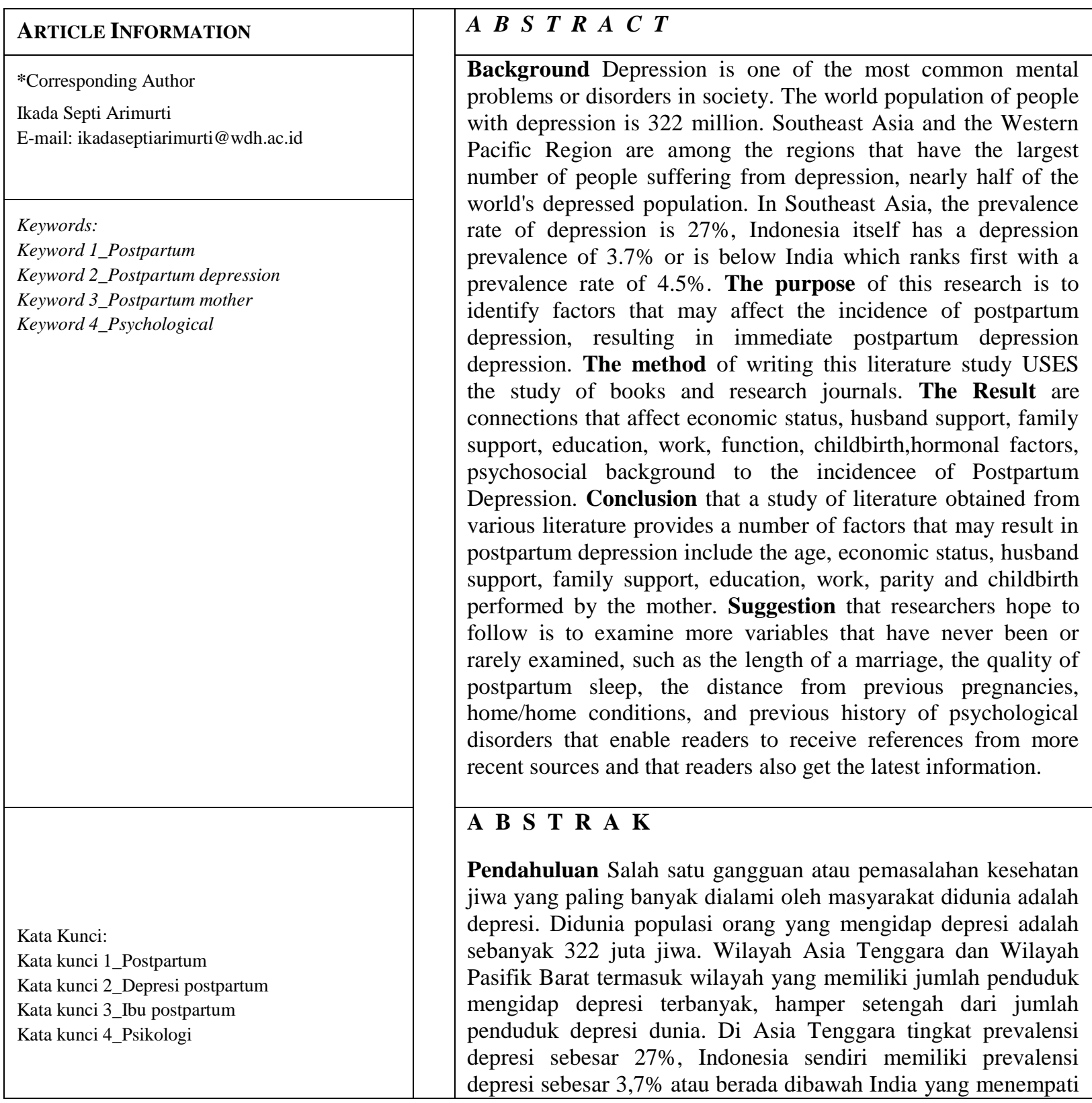




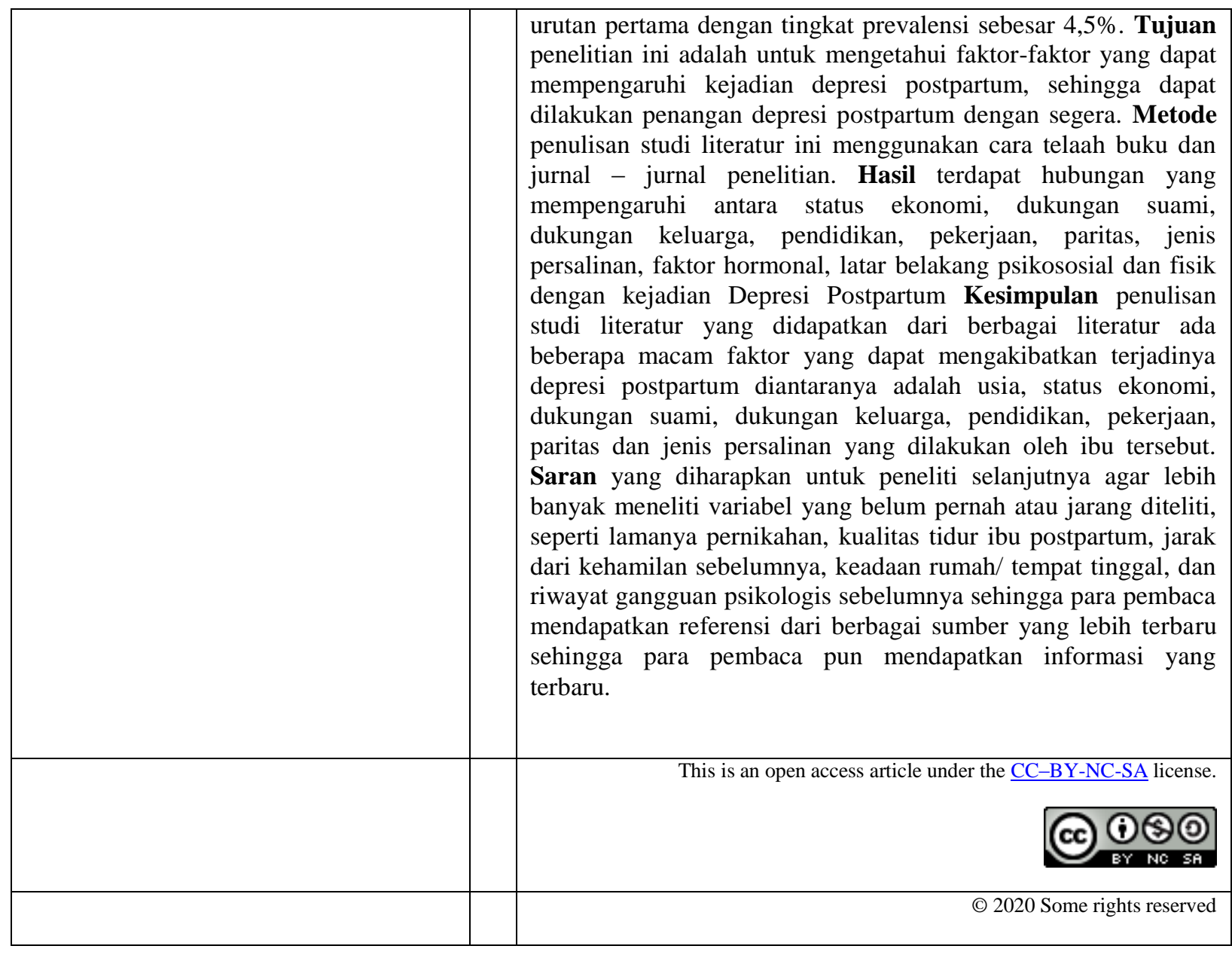




\section{PENDAHULUAN}

Depresi merupakan satu gangguan atau permasalahan kesehatan jiwa yang paling banyak dialami oleh masyarakat diseluruh dunia. Angka keterjadian tingkat depresi diseluruh dubia mencapai $18 \%$ pada periode tahun 2005 hingga 2015 atau sebesar 300 juta jiwa dari seluruh populasi didunia. Angka tersebut termasuk depresi yang dialami ibu pada masa postpartum atau masa nifas. Karena hal tersebut, depresi menjadi membutuhkan perhatian khusus terhadap gangguan masalah kejiwaan tersebut. WHO pada peringatan hari kesehatan sedunia tahun 2017 menjadikan depresi sebagai tema peringatan tahun tersebut (Kemenkes RI, 2017).

Berdasarkan data dari WHO, penduduk dengan kondisi depresi sebesar 322 juta jiwa diseluruh dunia. Asia Tenggara dan Pasifik Barat merupakan wilayah dengan populasi depresi terbanyak. Indonesia sendiri memiliki prevalensi depresi sebesar $3,7 \%$ atau berada dibawah India yang menempati urutan pertama dengan tingkat prevalensi sebesar 4,5\%, sedangkan depresi di wilayah Asia Tenggara sebesar 27\% (World Health Organization, 2017).

Data Angka kematian ibu di dunia pada tahun 2017 sekitar 295.000 ibu meninggal selama dan setelah persalinan. Mayoritas dari angka kematian ini (94\%) terjadi pada lingkungan sumber daya rendah dan kebanyakan dapat dicegah. Pada tahun 2017, Wilayah Asia Selatan dan Afrika sub-sahara memiliki angka kematian yang sangat besar yaitu menyumbang sebesar 86\% dari perkiraan Angka Kematian Ibu di dunia. Dimana, Wilayah Afrika subsahara sekitar dua pertiga dari total perkiraan Angka Kematian Ibu di dunia atau sebesar 196.000 kematian Ibu, sementara Asia Selatan menyumbang hampir seperlima atau 58.000 kematian ibu (WHO,2017).

Karena hal tersebut, periode kehamilan dan persalinan memiliki potensi stres yang lebih besar dibanding kondisi lainnya. Ibu dalam masa kehamilan dan masa melahirkan (postpartum) memiliki kecenderungan mengalami kondisi stress yang besar. Hal ini diakibatkan terbatasnya kondisi fisik ibu sehingga membatasi aktivitas fisik dalam proses adaptasi psikologis (Prawirohardjo, 2014). Kondisi tersebut dapat berlangsung selama ibu tersebut hamil dan saat masa nifas yang berlangsung selama 6 minggu atau 42 hari setelah persalinan.

Periode adaptasi psikologis ibu berawal ketika dia mengalami proses hamil hingga persalinan dengan disertai stress yang signifikan. Pada saat tersebut ibu mengalami perasaan sedih yang berkaitan dengan bayinya, kondisi ini disebut postpartum blues dan baby blues (Marmi, 
2012). Seperti disebutkan sebelumnya kondisi depresi juga dapat erjadi pada periode setelah persalinan atau postpartum. Depresi postpartum diibaratkan pencuri yang mencuri kebahagiaan dan kasih sayang dari seorang ibu yang nantinya akan diberikan kepada bayinya. Disamping itu, ibu yang mengidap depresi postpartum juga mengalami kesulitan dalam melakukan atau menjalani aktivitasnya (American Psychological Association, 2017).

Ada beberapa faktor yang mempengaruhi depresi postpartum ini diantaranya usia, status ekonomi, dukungan suami, dukungan keluarga, pendidikan, pekerjaan, status obsetri, jenis persalinan, dan kesiapan merawat bayi.

\section{METODE}

Metode yang akan digunakan pada penulisan studi literatur ini yaitu peneliti melakukan pendalaman pembahasan berdasarkan literatur yang didapatkan, yaitu berasal dari buku, teks ataupun jurnal.

\section{HASIL}

Terdapat beberapa faktor yang mempengaruhi kejadian depresi postpartum antaralain, status ekonomi, dukungan suami, dukungan keluarga, pendidikan, pekerjaan, paritas, jenis persalinan, faktor hormonal, latar belakang psikososial dan kondisi fisik.

\section{PEMBAHASAN}

\section{Usia}

Menurut penelitian Fathunikmah, dkk (2010) didapatkan hasil, 59,26\% ibu nifas yang mengalami kecendrungan depresi terjadi pada umur 20-35 tahun dan 14,82 $\%$ pada usia > 35 tahun, hal ini mengindikasikan terdapat hubungan antara kejadian depresi postpartum dengan usia ibu.

Hal yang berbeda diungkapkan Martinnia (2020), hasil penelitiannya menemukan bahwa usia ibu yang berusia 25-34 tahun lah yang beresiko lebih besar mengalami depresi postpartum dengan presentasi $42,8 \%(\mathrm{p}$-value $=0,02)$.

\section{Status Ekonomi}

Berdasarkan hasil penelitian yang dilakukan oleh Riani (2013) di RSIA Siti Fatimah Makassar, diketahui bahwa terdapat hubungan yang signifikan antara status ekonomi dengan tingkat depresi postpartum pada pasien post partum (pvalue $=0,001)$. Sejalan dengan penelitian yang dilakukan oleh Nurfatimah (2018), ibu post partum yang mengalami depresi pasca partum adalah ibu dalam kondisi ekonomi yang rendah $(\mathrm{p}$-value $=0,03)$. 


\section{Dukungan Suami}

Menurut hasil penelitian Cindritsya (2019) di Puskesmas Tuminting Manado, terdapat hubungan signifikan antara ibu hamil dengan kondisi depresi postpartum dengan dukungan suami yang baik ( $\mathrm{p}$-value $=$ 0,04). Sebanding dengan penelitian yang dilakukan oleh Martini Fairus (2014) hasil analisis multivariat di Puskesmas Rumbia dan Puskesmas Putra Rumbia tahun 2013 antara dukungan suami dan kejadian depresi postpartum menunjukkan terdapat hubungan signifikan antara keduannya (pvalue $=0,000$ ). Dari penelitian tersebut, Ibu nifas tanpa adanya dukungan suami mempunyai peluang 6,013 kali mengalami depresi postpartum dibandingkan dengan ibu nifas yang memperoleh dukungan suami.

\section{Dukungan Keluarga}

Berdasarkan hasil penelitian oleh Riani (2013) di RSIA Siti Fatimah Makassar menunjukkan bahwa terdapat hubungan yang signifikan antara dukungan keluarga dengan tingkat depresi pada pasien postpartum ( $\mathrm{p}$-value $=0,000)$. Hal yang sama juga diungkapkan oleh Nurfatimah (2018), hasil penelitian menungkapkan bahwa dukungan keluarga terhadap ibu pasca persalinan yang rendah berisiko sebesar 5,278 kali lebih besar untuk memicu terjadinya depresi pascasalin dibandingkan kondisi yang terjadi pada ibu pasca persalinan dengan dukungan sosial keluarga yang tinggi ( $\mathrm{p}$-value $=0,035$ dan OR 5,278).

\section{Pendidikan}

Berdasarkan hasil penelitian Ariyanti (2016), menunjukan pendidikan ibu yang tinggi mempunyai pengaruh signifikan terhadap risiko depresi pasca persalinan dengan nilai $\mathrm{OR}=1,490$. Hal ini menunjukkan ibu dengan dengan pendidikan tinggi memiliki risiko depresi pasca persalinan 1,490 kali lebih besar daripada ibu dengan tingkat pendidikan rendah. Hal yang sangat berbeda dikemukakan oleh Yusdiana (2011) pada penelitian terhadap ibu pasca melahirkan. Hasil penelitian tersebut menunjukkan bahwa ibu dengan tingkat pendidikan dasar mayoritas mengalami stress berat. Proporsi ini berbanding terbalik dengan ibu dengan pendidikan menengah, yang memiliki persentase sebesar $66,7 \%$ dan pendidikan tinggi $(44,0 \%)$. Hasil uji chi square menunjukkan bahwa ada hubungan signifikan antara tingkat pendidikan ibu dengan kejadian stres pasca trauma ( $\mathrm{p}$ value $=0,043)$.

\section{Pekerjaan}

Hasil penelitian yang dilakukan oleh Martinnia (2020), didapatkan hasil bahwa ibu yang bekerja sebagai karyawan memiliki peluang mengalami depresi postpartum lebih besar dibandingkan dengan ibu yang tidak bekerja $(\mathrm{p}$-value $=$ $0,03)$. 
Hal yang berbeda diketahui dari penelitian oleh Sri Wahyuni (2014), dalam penelitiannya menunjukkan bahwa pekerjaan terbukti berpengaruh terhadap kejadian depresi postpartum. Ibu yang tidak bekerja berisiko terjadinya depresi pasca melahirkan sebesar 10.7 kali lebih besar dibanding ibu yang bekerja.

\section{Paritas}

Berdasarkan hasil penelitian yang dilakukan Soep (2011), menyatakan bahwa terdapat perbedaan signifikan antara ibu primipara dan multipara terhadap risiko depresi pasca melahirkan dengan skala Edinburg. Soep menyatakan bahwa ibu primipara memiliki peluang lebih tinggi untuk mengalami depresi ( $\mathrm{p}$-value = $0,000)$.

Hal yang lain diungkapkan oleh Ariyanti (2016) dalam penelitiannya, paritas mempunyai pengaruh signifikan terhadap terjadinya risiko depresi pasca melahirkan dengan nilai $\mathrm{OR}=1$, artinya ibu status multigravida mempunyai resiko depresi pasca melahirkan 1 kali lebih besar daripada ibu status primigravida.

\section{Jenis Persalinan}

Jenis persalinan mempunyai pengaruh signifikan terhadap risiko depresi pasca melahirkan. Ibu dengan persalinan melalui operasi caesar mempunyai peluang risiko depresi pasca melahirkan 3,716 kali lebih besar dibandingkan ibu dengan persalinan normal atau pervaginam ( Ariyanti, 2016 ).
Hasil berbeda dikemukakan oleh Yusdiana (2011), dalam penelitiannya didapatkan hasil bahwa mayoritas ibu yang melakukan persalinan secara normal atau tidak terencana (spontan) mengalami stress berat atau sekitar $83,3 \%$. Sedangkan ibu partus dengan seksio caesaria dan vakum mempunyai perentase yang lebih kecil yaitu masing-masing sebesar $56,7 \%$ dan $50,0 \%$.

\section{Faktor Hormonal}

Faktor lainnya yang memiliki pengaruh terhadap depresi pasca melahirkan adalah hormon esterogen dan progesteron. Hormon yang mempunyai efek supresi aktifitas enzim monoamine oxidase, dimana enzim ini bekerja menginaktifasi baik nor adrenalin maupun serotonin sehingga berperan dalam mempengaruhi suasana hati maupun terjadinya depresi pada ibu melahirkan. Plasenta membentuk estrogen dalam bentuk aktif yaitu Estradiol dan estriol. Estradiol sendiri berfungsi untuk menguatkan fungsi neurotransmitter melalui peningkatan sintesis dan mengurangi pemecahan pada serotonin sehingga kadar estradiol yang turun dalam persalinan akan mengakibatkan depresi pasca persalinan (Thompson \& Fox, 2010).

Berdasarkan teori faktor hormonal sangat mempengaruhi kejadian depresi postpartum, namun belum ditemukan hasil 
penelitian terkait faktor hormonal dengan penyebab terjadinya depresi postparum.

\section{Latar Belakang Psikososial}

Pada penelitian yang dilakukan Kusuma (2019), ibu yang mengalami depresi postpartum hanya sebanyak $12,96 \%$ dengan kehamilan yang tidak diinginkan. Hal yang berbeda diperoleh Kumalasari (2019), yang mengatakan bahwa pada kehamilan yang tidak direncanakan sangat mempengaruhi kejadian depresi pasca persalinan $(\mathrm{p}$ value $=0,006)$.

\section{Fisik}

Menurut penelitian Kumalasari (2019), didapatkan hasil bahwa tingkat kelelahan ibu mempengaruhi kejadian depresi postpartum $(\mathrm{p}$-value $=0.029)$. Hasill yang hampir serupa dikemukakan oleh Mansur (2009) dalam penelitiannya, bahwa ada pengaruh kelelahan fisik akibat mengasuh bayi dengan kejadian kemurungan pasca melahirkan.

\section{KESIMPULAN}

Depresi Pasca melahirkan adalah depresi yang terjadi setelah proses melahirkan dan dapat berdampak negatif pada ibu yang mengalami, bayi yang dilahirkan, dan keluarga dari ibu tersebut. Ibu dengan kondisi depresi pasca melahirkan menolak untuk menyusui bayi dan ingin menyakiti diri sendiri (berpikir untuk bunuh diri) bahkan bisa menyakiti bayinya sendiri.

Tanda dan gejala pada ibu depresi pasca melahirkan antara lain: mood yang selalu berubah, pola tidur yang terganggu, gangguan pada pola makan, perubahan mental yang signifikan, perubahan libido, munculnya fobia atau ketakutan sehingga menyakiti diri sendiri atau bayinya.

Terdapat faktor penyebab timbulnya depresi pasca melahirkan yaitu faktor usia, hormonal, status ekonomi, dukungan suami, dukungan keluarga, pendidikan, status pekerjaan, stauts paritas maupun jenis persalinan yang dilakukan.

Depresi pasca melahirkan dapat dicegah dengan cara antara lain : menghindari pekerjaan atau kegiatan tidak penting, olahraga, meminta bantuan keluarga untuk melakukan aktifitas dan rekreasi

Terdapat beberapa cara yang dapat dilakukan agar resiko terjadinya depresi pasca melahirkan dapat berkurang, antara lain persiapan ibu hamil yang baik, olahraga yang cukup, support mental dari lingkungan sekitar, ungkapkan apa yang dirasakan dan mencari tau atau mempelajari tentang depresi postpartum, menghindari hidup yang drastis, dan melakukan pekerjaan rumah tangga dengan sewajarnya.

\section{DAFTAR PUSTAKA}

American Psychology Association. 2017. Diagnostic and Statistical Manual of Mental Disorders, VA: Marecan Psychology Publishing Arlington. 
Ariyanti, Ririn. 2016. Pengaruh Jenis Persalinan Terhadap Risiko Depresi Postpartum. Jurnal Kesehatan Samodra Ilmu Vol.7. No.2. Diakses Pada Tanggal 30 Maret 2020.

Cindritsya, Tolongan, dkk. 2010. Dukungan Suami dengan Kejadian Depresi Pasca Melahirkan. Jurnal Keperawatan. Vol 7. No 3. Diakses Pada Tanggal 30 Maret 2020.

Fathunikmah, Siska Heliani, dan Nur. 2010. Karakteristik Prevalensi Kencendurungan Depresi Postpartum Dengan Menggunakan EDINBURGH POSATAL DEPRESSION SCALE (EPDS) DI RB Afiyah Pekanbaru Tahun 2010. Jurnal Vol2. No.4. Diakses Pada Tanggal 31 Maret 2020.

Fairus, Martini. 2014. Hubungan Dukungan Suami Dengan Kejadian Depresi Postpartum Pada Ibu Nifas. Jurnal Kesehatan Metro Sai Wawai Volume VII No.1. Diakses Pada Tanggal 30 Maret 2020.

Kementerian Kesehatan Republik Indonesia. 2017. Profil Kesehatan Indonesia. Jakarta:KEMENKES RI. Diakses Pada Tanggal 20 Januari 2020

Kumalasari, Intan, Hendawati. 2019. Faktor Resiko Kejadian Postpartum Blues di Kota Palembang. Jurnal Kesehatan Poltekkes Palembang. Vol 14.No.2. Diakses Pada Tanggal 20 Mei 2020.

Kusuma, Ratu. 2019. Karakteristik Ibu yang Mengalami Depresi Postpartum. Jurnal Ilmiah Universitas Batanghari Jambi. Vol 19. No.1. Diakses pada tanggal 18 Mei 2020.
Mansur, \& Herawati. 2009. Psikologi Ibu Dan Anak Untuk Kebidanan. Jakarta: Salemba Medika.

Marmi. 2012. Asuhan Kebidanan Pada Masa Nifas "Puerperium Care". Yogyakarta: Pustaka Pelajar. Diakses Pada Tanggal 18 Februari 2020.

Martinnia, Nasrin. Saeid, Yazdi. R. 2020. Postpartum Depression Among Women With Previous Infertility in Health Care Centers of Hamadan. Journals.sbmu.ac.ir. Vol 7, No 2. Diakses Pada Tanggal 4 April 2020.

Nurfatimah, Christina Enoth. 2018. Hubungan Faktor Demografi dan Dukungan Sosial Dengan Depresi Pascasalin. Jurnal Profesi Medika. Vol.11 No.2. Diakses Pada Tanggal 30 Maret 2020.

Prawirohardjo, Sarwono. 2014. llmu Kebidanan. Jakarta. Bina pustaka Sarwono Prawirohardjo.

Riani, Idel. Muhammad, Nur. 2013. Faktor Yang Mempengaruhi Tingkat Depresi Pada Pasien Postpartum di RSIA Siti Fatimah Makassar. Jurnal Keperawatan No.1 Vol.6. Diakses Pada Tanggal 30 Maret 2020

Soep. 2011. Penerapan Edinburgh Postpartum Depression Scale sebagai Alat Deteksi Resiko Depresi Nifas pada Primipara dan Multipara. Jurnal Keperawatan Indonesia Vol. 14, No 2, Juli 2011; Hal 95-100.

Thompson, K.S \& Fox,J.E. 2010.Postpartum Depression : a Comprehensive Approach to Evaluation and Treatment. Ment Health Fam Med, Diakses Pada tanggal 26 Mei 2020. 
Wahyuni, Sri. 2014. Faktor Internal dan Eksternal Yang Mempengaruhi Depresi Postpartum. Jurnal Terpadu Ilmu Kesehatan. Vol 3. No.2. Diakses Pada Tanggal 30 Maret 2020.

World Health Organization. 2017. Depression and Other Common Mental Disorder:Global Health Estimates. WHO. Diakses Pada Tanggal 19 February 2020.

Yusidiana, Dina. 2011. Perbedaan Kejadian Stress Pasca Trauma Pada Ibu Post Partum Dengan Seksio Sesaria Emergenci, Partus Pervagina Dengan Partus Spontan. Jurnal Keperawatan Indonesia Vol. 14. No.3. Diakses Pada Tanggal 31 Maret 2020. 